\title{
Milk fatty acid composition of dairy goats fed increasing levels of Flemingia macrophylla hay
}

\section{Perfil de ácidos graxos do leite de cabras alimentadas com feno de Flemingia macrophylla}

\author{
Isabel das Neves Oiticica ${ }^{1}$; Carlos Elysio Moreira da Fonseca²; Fernando César \\ Ferraz Lopes ${ }^{3}$; Mirton José Frota Morenz ${ }^{4 *}$; Marco Antônio Sundfeld da Gama \\ Vinícius Carneiro de Souza ${ }^{5}$; Aline Barros da Silva ${ }^{6}$
}

\begin{abstract}
The effect of dietary inclusion of increasing levels of Flemingia macrophylla hay on the yield, composition and fatty acid profile of milk from Saanen x Boer goats was evaluated. The diets were composed of $40 \%$ concentrate and $60 \%$ forage. The treatments were defined by the level of inclusion of Flemingia hay in the diet $\left(0,80,160,240\right.$ and $320 \mathrm{~g} \mathrm{~kg}^{-1}$ dry matter $)$ in replacement of the Cynodon dactylon cv. Tifton- 85 hay, distributed according to a 5 x 5 Latin Square design. The inclusion of Flemingia in the diet did not change the milk yield or milk fat content but promoted a quadratic effect on the fat yield. A quadratic effect was observed on the milk protein and lactose contents, but this effect was not reflected in the daily production of these components. The concentrations of vaccenic, rumenic, elaidic and trans-10 C18:1 fatty acids in milk fat increased linearly in response to the dietary inclusion of Flemingia, whereas the contents of palmitic, stearic, oleic, linoleic and $\alpha$-linolenic fatty acids were not modified. A linear reduction was observed in the lauric and myristic fatty acids concentrations, which was accompanied by a reduction in the atherogenic index of milk fat. A quadratic effect was also observed on the trans-10, cis-12 CLA milk fat content in response to the inclusion of Flemingia in the diet, as well as a linear increase in the apparent transfer of $\alpha$-linolenic acid from the diet to milk. The inclusion of up to $320 \mathrm{~g} \mathrm{~kg}^{-1}$ of Flemingia hay as a replacement for Tifton-85 hay in the Saanen x Boer dairy goat diet does not modify the milk production and improves the nutritional quality of milk fat by increasing the contents of rumenic and vaccenic acids beneficial to human health and reducing the concentrations of hypercholesterolemic fatty acids.
\end{abstract}

Key words: Conjugated linoleic acid. Fabaceae. Leguminous. Rumenic acid. Vaccenic acid.

1 Dr ${ }^{\mathrm{a}}$ em Zootecnia, Universidade Federal Rural do Rio de Janeiro, UFRRJ, Programa de Pós-Graduação em Zootecnia, Seropédica, RJ, Brasil. E-mail: isabeloiticica@gmail.com

2 Prof. Associado, UFRRJ, Programa de Pós-Graduação em Zootecnia, Seropédica, RJ, Brasil. E-mail: carloselysio@hotmail.com

3 Analista, Empresa Brasileira de Pesquisa Agropecuária, EMBRAPA Gado de Leite, Juiz de Fora, MG, Brasil. E-mail: fernando. lopes@embrapa.br

4 Pesquisadores, EMBRAPA Gado de Leite, Juiz de Fora, MG, Brasil. E-mail: mirton.morenz@embrapa.br; marco.gama@ embrapa.br

5 Discente do Curso de Doutorado do Programa de Pós-Graduação em Zootecnia, Universidade Estadual Paulista Júlio de Mesquita Filho, Jaboticabal, SP, Brasil. E-mail: vinicius2042@hotmail.com

6 Discente. Curso de Doutorado, Programa de Pós-graduação em Zootecnia, Universidade Federal Rural do Rio de Janeiro, Seropédica, RJ, Brasil. E-mail: aline_barros2006@hotmail.com

* Author for correspondence 


\section{Resumo}

Foi avaliado o efeito da inclusão dietética de níveis crescentes de feno de Flemingia macrophylla sobre a produção, a composição e o perfil de ácidos graxos do leite de cabras Saanen x Boer. As dietas foram compostas por $40 \%$ de concentrado e $60 \%$ de forragem. Os tratamentos foram definidos pelo nível de inclusão de feno de Flemingia à dieta $\left(0,80,160,240\right.$ e $320 \mathrm{~g} \mathrm{~kg}^{-1}$ de matéria seca) em substituição ao feno de Cynodon dactylon cv. Tifton-85, distribuídos segundo delineamento em Quadrado Latino 5 x 5 . A inclusão de Flemingia na dieta não alterou a produção de leite e seu teor de gordura, mas promoveu efeito quadrático sobre a produção de gordura. Houve efeito quadrático sobre os teores de proteína e lactose do leite, mas sem reflexo sobre as produções diárias destes componentes. Os teores dos ácidos rumênico, vacênico, elaídico e C18:1 trans-10 na gordura do leite aumentaram linearmente em resposta à inclusão de Flemingia na dieta, enquanto que os teores dos ácidos palmítico, esteárico, oleico, linoleico e $\alpha$-linolênico não foram alterados. Houve redução linear nos teores dos ácidos láurico e mirístico, o que foi acompanhado por redução do índice de aterogenicidade da gordura do leite. Observou-se ainda efeito quadrático sobre o teor do CLA trans-10, cis-12 na gordura do leite em resposta à inclusão de Flemingia à dieta, bem como incremento linear na transferência aparente do ácido $\alpha$-linolênico da dieta para $o$ leite. Concluiu-se que a inclusão de até $320 \mathrm{~g} \mathrm{~kg}^{-1}$ de matéria seca de feno de Flemingia macrophylla em substituição ao feno de Tifton- 85 na dieta de cabras Saanen x Boer não altera a produção diária de leite e melhora a qualidade nutricional da gordura do leite por meio do incremento dos teores dos ácidos rumênico e vacênico, benéficos à saúde humana, e redução das concentrações de ácidos graxos hipercolesterolêmicos.

Palavras-chave: Ácido linoleico conjugado. Ácido rumênico. Ácido vacênico. Fabaceae. Leguminosa.

\section{Introduction}

Flemingia macrophylla (Willd.) Kuntze ex Merrill is a tropical, shrubby, perennial legume from Asia that exhibits vigorous growth and good regrowth ability after cutting and develops well on acidic, poorly drained and low-fertility soils. It shows good tolerance to shade and water stress, remaining green for up to 4 months during the dry period of the year. It has been recommended as an alternative forage for feeding small ruminants, mainly in family-based production systems, during periods of seasonal fodder production or as a substitute for bulky or concentrated foods (MUI et al., 2001; ANDERSSON et al., 2002, 2006).

In addition to presenting high protein content, ranging from 169 to $237 \mathrm{~g} \mathrm{~kg}^{-1}$ dry matter (DM) (ANDERSSON et al., 2006), Flemingia is also rich in secondary compounds such as condensed tannins (CT) at concentrations higher than $5 \mathrm{~g} \mathrm{~kg}^{-1}$ DM (JACKSON et al., 1996; TIEMANN et al., 2008; FAGUNDES et al., 2014). For this reason, in studies with sheep (BARAHONA et al., 1997;
KEXIAN et al., 1998; TIEMANN et al., 2008) and growing goats (KEXIAN et al., 1998; MUI et al., 2001) and with lactating goats (FAGUNDES et al., 2014; OITICICA et al., 2015), the foraging potential of this legume always has been evaluated with emphasis on the supposed effects of $\mathrm{CT}$ on nutrient intake and digestibility, nitrogen $(\mathrm{N})$ and energy compound metabolism, and therefore on the productive performance of the animals.

However, in studies carried out in vitro and in vivo in sheep (KHIAOSA-ARD et al., 2009; VASTA et al., 2009a, b), the addition of CT in the incubation substrate or in the animal's diet promoted an increase of vaccenic acid (trans-11 C18:1) in the ruminal fluid, which may be indicative of an inhibition in the last step of the biohydrogenation (BH) of the unsaturated $\mathrm{C} 18$ fatty acids (FA) to stearic acid (C18:0) in the rumen. Notably, in goats, the vaccenic acid is responsible for $63 \%$ to $73 \%$ of the total secretion of rumenic acid (cis-9, trans-11 CLA) in milk (BERNARD et al., 2010); rumenic acid is a compound related to anticarcinogenic, antidiabetogenic (type 2 diabetes), antiatherogenic 
and immunomodulatory properties (KOBA; YANAGITA, 2014; YANG et al., 2015). Therefore, milk and dairy products naturally enriched with these two FAs, in addition to providing other health benefits, such as those provided by oleic (cis-9 C18:1) and $\alpha$-linolenic acids (cis-9, cis-12, cis-15 C18:3), are desirable for human consumption, being considered functional foods of high added value.

Fagundes (2012) evaluated the inclusion of 125 and $250 \mathrm{~g} \mathrm{~kg}^{-1} \mathrm{DM}$ of Flemingia hay in the diet of goats and did not observe an effect on milk yield, milk composition and FA profile, except for the lauric acid content (C12:0), which was reduced with an increase of Flemingia in the diet. However, other FAs of interest to human health (e.g., vaccenic and rumenic acids) were not reported in the study.

The objective of this study was to evaluate the milk production and its components, as well as the milk fatty acid composition, of Saanen x Boer dairy goats fed diets containing increasing levels of Flemingia macrophylla hay in replacement of the Cynodon dactylon cv. Tifton-85 hay.

\section{Materials and Methods}

The experiment was conducted from August to December 2011 at the Federal Rural University of Rio de Janeiro - UFRRJ (Seropédica, RJ, Brazil). All experimental procedures used followed the principles of ethics and animal welfare of UFRRJ.

Five Saanen $\mathrm{x}$ Boer dairy goats, multiparous, with 55 to 65 days of lactation, were used. Milk production was $1.49 \mathrm{~kg} \mathrm{~d}^{-1}$ at the beginning of the study. The goats were kept in individual stalls, with water and mineral mixture ad libitum, in addition to a trough to hold the diet. A 5 x 5 Latin Square (LS) experimental design was used. The experimental period lasted 11 days, comprising 7 days for adaptation, followed by a sampling period from days 8 to 11. A fixed forage-to-concentrate ratio of 60:40 was used, and the treatments were defined by the level of inclusion of Flemingia hay in the diet $\left(0,80,160,240\right.$ and $\left.320 \mathrm{~g} \mathrm{~kg}^{-1} \mathrm{DM}\right)$, which replaced the Tifton- 85 hay. The centesimal and chemical compositions of the experimental diets, as well as the FA profile of the ingredients, are shown in Tables 1 and 2, respectively.

Table 1. Proportion of the ingredients and chemical composition of the experimental diets.

\begin{tabular}{lccccc}
\hline \multirow{2}{*}{ Ingredient } & \multicolumn{5}{c}{ Flemingia hay $\left(\mathrm{g} \mathrm{kg}^{-1}\right.$ dry matter $)$} \\
\cline { 2 - 6 } & 0 & 80 & 160 & 240 & 320 \\
\hline Tifton-85 hay & 600 & 520 & 440 & 360 & 280 \\
Flemingia hay & 0 & 80 & 160 & 240 & 320 \\
Ground corn & 362 & 366 & 368 & 372 & 375 \\
Soybean meal & 38 & 34 & 32 & 28 & 25 \\
\hline Nutrient (g kg-1 dry matter) & & & & 840 & 853 \\
\hline Dry matter (g kg-1) & 830 & 837 & 140 & 140 & 140 \\
Crude protein & 140 & 140 & 30 & 31 & 32 \\
Ether extract & 27 & 29 & 462 & 456 & 450 \\
Neutral detergent fiber & 474 & 468 & 245 & 255 & 266 \\
Acid detergent fiber & 224 & 234 & 61 & 76 & 88 \\
Lignin & 35 & 48 & 44 & 44 & 43 \\
Mineral matter & 45 & 45 & & & \\
\hline Fatty acid (g kg-1 dry matter) & & & & & \\
\hline Myristic acid (C14:0) & 0.06 & 0.06 & 0.06 & \\
& & & & & continue
\end{tabular}


continuation

Palmitic acid (C16:0)

5.47

5.47

5.46

5.46

5.46

Stearic acid (C18:0)

0.65

0.67

0.69

0.71

0.73

Oleic acid (cis-9 C18:1)

8.18

8.27

8.31

8.40

8.46

Linoleic acid (cis-9, cis-12 C18:2)

11.40

11.47

11.51

11.58

11.64

$\alpha$-linolenic acid (cis-9, cis-12, cis-15 C18:3)

1.39

1.28

1.17

0.94

Table 2. Fatty acid composition of the feed ingredients used in the experimental diets.

\begin{tabular}{lcccc}
\hline \multirow{2}{*}{$\begin{array}{l}\text { atty acid - FA } \\
\left(\mathrm{g} 100 \mathrm{~g}^{-1} \mathrm{FA}\right)\end{array}$} & Tifton-85 hay & Flemingia hay & Soybean meal & Ground corn \\
\hline Myristic acid & 0.87 & 1.12 & 0.13 & 0.06 \\
Palmitic acid & 36.0 & 38.8 & 19.2 & 14.7 \\
Stearic acid & 3.59 & 7.05 & 3.50 & 1.86 \\
Oleic acid & 5.49 & 8.52 & 15.84 & 34.47 \\
Linoleic acid & 13.0 & 16.9 & 52.8 & 45.4 \\
$\alpha$-linolenic acid & 20.6 & 6.24 & 4.91 & 0.95 \\
$\Sigma$ identified FA $/ \Sigma$ total FA & 0.80 & 0.79 & 0.97 & 0.96 \\
\hline
\end{tabular}

The diets were fed ad libitum ( $15 \%$ leftovers) in a total mixed ration (TMR) twice a day (07h30 and 14h30), shortly after milking, which was performed manually at $07 \mathrm{~h} 00$ and $14 \mathrm{~h} 00$.

Flemingia planting for hay production was carried out at Embrapa Agrobiologia (Seropédica, RJ). After cutting the plants at $1 \mathrm{~m}$ above the ground, the fractions composed of leaves and thin stems were sun dried for 2 days. The obtained hay was bagged and stored in a suitable place until its use. Samples from Flemingia and Tifton- 85 hays, as well as ground corn and soybean meal, were collected and stored at $-10^{\circ} \mathrm{C}$ for determination of the FA profile according to procedures described by Ribeiro et al. (2014). This analysis was performed at Embrapa Dairy Cattle Chromatography Laboratory (Juiz de Fora, MG, Brazil) using a $6890 \mathrm{~N}$ gas chromatograph equipped with a HPFFAP capillary column $(25 \mathrm{~m} \times 0.20 \mathrm{~m} \times 0.33$ $\mu \mathrm{m})$ of polyethylene glycol (Agilent Technologies Inc., Santa Clara, CA, USA) and flame ionization detector (FID). The quantification of FA in the sample $\left(\mathrm{g} \mathrm{kg}^{-1} \mathrm{DM}\right)$ was performed by the addition of an internal standard (C19:0).

On the $10^{\text {th }}$ day of each LS period, after recording production, aliquots of milk from each milking (2/3 at morning milking $+1 / 3$ at afternoon milking) were collected to compose individual samples, which were stored at $-10^{\circ} \mathrm{C}$ in flasks without preservative, for determination of the milk FA composition by gas chromatography, as described by Ribeiro et al. (2014). This analysis was performed in the Chromatography Laboratory of Embrapa Dairy Cattle using a model 7820A Gas Chromatograph system (Agilent Technologies Inc., Santa Clara, CA, USA) equipped with a $100 \mathrm{~m} \times 0.25 \mathrm{~mm} \times 0.2$ $\mu \mathrm{m}$ fused silica capillary column (CP-Sil 88, Varian Inc., Mississauga, ON, USA) and FID. In another flask containing bronopol preservative, samples were collected for the determination of protein, fat, lactose, solids-not-fat and total solids milk contents. These analyses were performed at the Embrapa Dairy Cattle Milk Quality Laboratory (Juiz de Fora, MG) by medium infrared spectrometry (Bentley 2000, Bentley Instruments Inc., Chaska, MN, USA). 
To complement the nutritional quality assessment of the milk fat, atherogenicity (AI) and thrombogenicity (TI) indexes and relationships between omega 6 and omega 3 FA ( $\omega-6: \omega-3$ FA ratio) and hypo- and hypercholesterolemic FA (h/H FA ratio) were calculated according to the following equations as described by Silva et al. (2017): $\mathrm{AI}=$ $[\mathrm{C} 12: 0+(4 * \mathrm{C} 14: 0)+\mathrm{C} 16: 0] /($ cis $-9 \mathrm{C} 18: 1+\Sigma$ cis $\omega-6 \mathrm{FA}+\Sigma$ cis $\omega-3 \mathrm{FA}) ; \mathrm{TI}=(\mathrm{C} 14: 0+\mathrm{C} 16: 0+$ $\mathrm{C} 18: 0) /\left[\left(0.5^{*}\right.\right.$ cis $\left.-9 \mathrm{C} 18: 1\right)+(0.5 * \Sigma$ cis $\omega-6 \mathrm{FA})+$ $\left(3^{*} \Sigma\right.$ cis $\left.\omega-3 \mathrm{FA}\right)+(\Sigma$ cis $\omega-3 \mathrm{FA} / \Sigma$ cis $\left.\omega-6 \mathrm{FA})\right]$; $\omega-6: \omega-3$ FA ratio $=\Sigma$ cis $\omega-6 / \Sigma$ cis $\omega-3$ FA; and $\mathrm{h} / \mathrm{H}$ FA ratio $=($ cis-9 C18:1 $+\Sigma$ cis $\omega-3$ FA $) /(\mathrm{C} 12: 0+$ C14:0 + C16:0), where $\Sigma$ cis $\omega-3$ FA $=$ cis-6, cis-9, cis-15 C18:3 + C20:5 $\omega-3 \mathrm{EPA}$, and $\Sigma$ cis $\omega-6 \mathrm{FA}=$ cis-9, cis-12 C18:2 + cis-6, cis-9, cis-12 $\gamma-\mathrm{C} 18: 3+$ cis-11, cis-14 C20:2 + cis-8, cis-11, cis-14 C20:3 + cis-5, cis-8, cis-11, cis-14 C20:4.

Indexes of the activity of stearoyl-CoA desaturase enzyme (SCD) and FA secretion in milk were calculated as described by Mourthé et al. (2015).

The results were analyzed by mixed models, using the MIXED procedure of SAS version 9.0. The level of inclusion of Flemingia hay in the diet was considered a fixed effect, and the LS period and the goat were considered random effects. The linear and quadratic effects were analyzed by orthogonal contrasts. Regression equations between variables were adjusted using the REG procedure, and Pearson correlations were obtained using the CORR procedure. Effects were considered significant when $\mathrm{P} \leq 0.05$.

\section{Results and Discussion}

The inclusion of Flemingia in the diet did not affect $(\mathrm{P}>0.05)$ the milk yield nor the productions of protein, lactose, solids-not-fat and total solids $\left(\mathrm{g} \mathrm{d}^{-1}\right)$ as shown in Table 3. On the other hand, a quadratic effect $(\mathrm{P}<0.05)$ was observed on the production of the fat and on the fat-corrected milk (FCM) yield $\left(\mathrm{g} \mathrm{d}^{-1}\right)$. The minimum production of fat $\left(38.9 \mathrm{~g} \mathrm{~d}^{-1}\right)$ and FCM yield $\left(1,273 \mathrm{~g} \mathrm{~d}^{-1}\right)$, estimated from the regression equations, corresponded to the inclusion of 158 and $165 \mathrm{~g} \mathrm{~kg}^{-1} \mathrm{DM}$ from Flemingia hay in the diet, respectively.

No effect $(\mathrm{P}>0.05)$ of inclusion of Flemingia in the diet was observed on the fat and total solids milk content $\left(\mathrm{g} \mathrm{kg}_{-}{ }^{1}\right)$ (Table 3). However, a quadratic effect $(\mathrm{P}<0.05)$ was observed on the protein, lactose and consequently, on the solids-not-fat milk content. The maximum levels of protein, lactose and solidsnot-fat in milk $\left(25.2,40.5\right.$ and $\left.72.8 \mathrm{~g} \mathrm{~kg}^{-1}\right)$, estimated from the regression equations, corresponded to the inclusions of 163,159 and $168 \mathrm{~g} \mathrm{~kg}^{-1} \mathrm{DM}$ from Flemingia hay in the diet, respectively.

Table 3. Milk production and composition of Saanen x Boer goats fed diets containing increasing levels of Flemingia hay.

\begin{tabular}{|c|c|c|c|c|c|c|c|c|}
\hline \multirow{2}{*}{ Item } & \multicolumn{5}{|c|}{ Flemingia hay ( $\mathrm{g} \mathrm{kg}^{-1}$ dry matter) } & \multirow{2}{*}{ SEM $^{1}$} & \multicolumn{2}{|c|}{$\mathrm{P}$-value } \\
\hline & 0 & 80 & 160 & 240 & 320 & & Linear & Quadratic \\
\hline \multicolumn{9}{|c|}{ Yield $\left(\mathrm{g} \mathrm{d}^{-1}\right)$} \\
\hline Milk & 1,511 & 1,552 & 1,443 & 1,482 & 1,486 & 121.36 & 0.3072 & 0.5917 \\
\hline $\mathrm{FCM}^{2}$ & 1,403 & 1,344 & 1,261 & 1,287 & 1,413 & 192.72 & 0.8008 & $0.0366^{*}$ \\
\hline Protein & 36.1 & 38.7 & 36.2 & 37.3 & 35.4 & 3.08 & 0.5131 & 0.3217 \\
\hline Fat & 46.2 & 41.5 & 39.2 & 39.8 & 47.4 & 8.98 & 0.9452 & $0.0412 *$ \\
\hline Lactose & 60.0 & 62.6 & 58.0 & 59.8 & 59.1 & 4.17 & 0.3931 & 0.9528 \\
\hline
\end{tabular}


continuation

\begin{tabular}{lcccccccc} 
Solids-not-fat & 106.9 & 112.4 & 104.4 & 107.7 & 105.6 & 8.10 & 0.4754 & 0.7261 \\
Total solids & 153.0 & 153.9 & 143.7 & 147.5 & 149.5 & 15.83 & 0.3464 & 0.3405 \\
\hline \multicolumn{2}{l}{ Composition $\left(\mathrm{g} \mathrm{kg}^{-1}\right.$} & milk $)$ & & & & & & \\
\hline Protein & 24.0 & 24.9 & 24.9 & 25.2 & 23.9 & 0.79 & 0.8552 & $0.0070^{*}$ \\
Fat & 29.0 & 26.3 & 26.5 & 26.4 & 31.0 & 3.79 & 0.5731 & 0.0997 \\
Lactose & 40.0 & 40.4 & 40.3 & 40.5 & 39.9 & 0.72 & 0.9408 & $0.0154^{*}$ \\
Solids-not-fat & 71.1 & 72.5 & 72.3 & 72.9 & 71.3 & 1.39 & 0.6008 & $0.0094^{*}$ \\
Total solids & 100.0 & 98.8 & 98.8 & 99.4 & 100.3 & 3.79 & 0.8365 & 0.4523 \\
\hline
\end{tabular}

${ }^{1} \mathrm{SEM}$ - standard error of the mean. ${ }^{2} \mathrm{FCM}$ - Fat-corrected milk (SKLAN et al., 1992) $=(0.432+0.1625 *$ milk fat $) *$ milk yield.

*Regression equations: $\hat{\mathrm{y}}_{\mathrm{FCM} \text { yield }}=0.00533 \mathrm{x}^{2}-1.75448 \mathrm{x}+1,417.51611 ; \hat{\mathrm{y}}_{\text {fat yield }}=0.00030629 \mathrm{x}^{2}-0.09693 \mathrm{x}+46.56417$; $\hat{\mathrm{y}}_{\text {milk protein content }}=-0.00004598 \mathrm{x}^{2}+0.01496 \mathrm{x}+23.97143 ; \hat{\mathrm{y}}_{\text {milk lactose content }}=-0.00001964 \mathrm{x}^{2}+0.00624 \mathrm{x}+39.96857 ; \hat{\mathrm{y}}_{\text {milk }}$ solid-not-fat content $=-0.00006071 \mathrm{x}^{2}+0.02043 \mathrm{x}+71.08686$.

The results of the intake and digestibility from the present work were presented in a companion paper (OITICICA et al., 2005), in which the inclusion of Flemingia in the diet was reported to not affect the $\mathrm{DM}$ and total digestible nutrients intakes $(\mathrm{P}>0.05)$, which is consistent with the similarity between treatments for milk production, but those findings do not explain the quadratic behavior observed for other variables presented in Table 3. In this sense, some aspects related to milk fat content and production will be discussed later on the basis of the milk FA profile. Fagundes (2012) included 0, 125 and $250 \mathrm{~g} \mathrm{~kg}^{-1} \mathrm{DM}$ of Flemingia hay replacing Tifton- 85 hay and did not observe an effect $(\mathrm{P}>0.05)$ of the inclusion of the legume in the diet on the milk production and composition. The highest milk $\left(2.30 \mathrm{~kg} \mathrm{~d}^{-1}\right)$ and FCM $\left(1.74 \mathrm{~kg} \mathrm{~d}^{-1}\right)$ yield, as well as the highest protein, fat, lactose, total solids and solids-not-fat milk contents (respectively, 27.4, $34.8,43.2,114.6$ and $79.7 \mathrm{~g} \mathrm{~kg}^{-1}$ milk) observed by Fagundes (2012), when compared to the values obtained in the present experiment (Table 3), can be attributed, at least in part, to the differences in the forage:concentrate ratio and the days in milk of the goats used in the two studies.

The linear increases $(\mathrm{P}<0.05)$ observed in the myristic (C14:0), stearic, oleic and linoleic FA intakes, as well as the linear reduction $(\mathrm{P}<0.05)$ in $\alpha$-linolenic acid intake as Flemingia hay was added to the diet (Table 4) are mainly due to the differences in the relative proportions of these FA in the dietary ingredients (Table 2), since no effect $(\mathrm{P}>0.05)$ of the treatments was observed on the DM intake, which was, on average, $1.74 \mathrm{~kg} \mathrm{~d}^{-1}$ (OITICICA et al., 2015). For the three main substrates used in the ruminal $\mathrm{BH}$ processes, the diets with higher proportions of Flemingia in substitution for Tifton-85 had a lower $\alpha$-linolenic acid content and higher oleic and linoleic acids contents (Table 1) (SHINGFIELD et al., 2010). 
Table 4. Fatty acid intake of Saanen x Boer goats fed diets containing increasing levels of Flemingia hay.

\begin{tabular}{|c|c|c|c|c|c|c|c|c|}
\hline \multirow{2}{*}{ Fatty acid - FA $\left(\mathrm{g} \mathrm{d}^{-1}\right)$} & \multicolumn{5}{|c|}{ Flemingia hay ( $\mathrm{g} \mathrm{kg}^{-1}$ dry matter) } & \multirow[b]{2}{*}{ SEM $^{1}$} & \multicolumn{2}{|l|}{ P-value } \\
\hline & 0 & 80 & 160 & 240 & 320 & & Linear & Quadratic \\
\hline $\mathrm{C} 14: 0$ & 0.101 & 0.105 & 0.114 & 0.119 & 0.116 & 0.0068 & $0.0121^{*}$ & 0.3269 \\
\hline C16:0 & 8.88 & 9.17 & 9.77 & 10.10 & 9.72 & 0.5816 & 0.0667 & 0.3160 \\
\hline C18:0 & 1.05 & 1.12 & 1.23 & 1.31 & 1.29 & 0.0737 & $0.0015^{*}$ & 0.3388 \\
\hline cis-9 C18:1 & 13.29 & 13.85 & 14.87 & 15.53 & 15.07 & 0.8879 & $0.0213^{*}$ & 0.3229 \\
\hline cis-9, cis-12 C18:2 & 18.51 & 19.23 & 20.59 & 21.43 & 20.72 & 1.2278 & $0.0327^{*}$ & 0.3203 \\
\hline cis-9, cis-12, cis-15 C18:3 & 2.26 & 2.15 & 2.09 & 1.95 & 1.68 & 0.1226 & $0.0004 *$ & 0.2580 \\
\hline$\Sigma$ Oleic + Linoleic + Linolenic FA ${ }^{2}$ & 34.06 & 35.22 & 37.55 & 38.91 & 37.46 & 2.2369 & 0.0576 & 0.3170 \\
\hline$\Sigma$ Linoleic + Linolenic FA ${ }^{2}$ & 20.78 & 21.37 & 22.68 & 23.38 & 22.40 & 1.3491 & 0.1077 & 0.3133 \\
\hline
\end{tabular}

${ }^{1}$ SEM - standard error of the mean. ${ }^{2} \Sigma$ Substrate - Refers to the sum of the ingested FAs used in the rumen as a substrate for the vaccenic acid production (SHINGFIELD et al., 2010).

*Regression equations: $\hat{\mathrm{y}}_{\mathrm{C} 14: 0}=0.00005593 \mathrm{x}+0.10208 ; \hat{\mathrm{y}}_{\mathrm{C} 18: 0}=0.00083627 \mathrm{x}+1.06526 ; \hat{\mathrm{y}}_{\text {cis }-9 \mathrm{C} 18: 1}=0.00656 \mathrm{x}+$ $13.4722 ; \hat{\mathrm{y}}_{\text {cis- }- \text {, cis-12 } \mathrm{C} 18: 2}=0.00827 \mathrm{x}+18.77112 ; \hat{\mathrm{y}}_{\text {cis- }-9, \text { cis-12, cis-15 C18:3 }}=-0.00172 \mathrm{x}+2.29952$.

For goats fed alfalfa hay and non-lipid concentrates (forage:concentrate ratio of 30:70) with milk production of 1,256-1,988 $\mathrm{g} \mathrm{d}^{-1}$ and DM intake of 1.41-1.78 $\mathrm{kg} \mathrm{d}^{-1}$ (close to those observed in the present study), Shingfield et al. (2009) and Martínez Marín et al. $(2011,2012)$ reported intakes of 4.85.1, 4.3-6.9, 9.2-18.9 and 2.5-6.5 $\mathrm{g} \mathrm{d}^{-1}$, respectively, for palmitic, oleic, linoleic and $\alpha$-linolenic FA. In relation to these ranges, the palmitic, oleic and linoleic FA intakes presented in Table 4 were higher, whereas that of $\alpha$-linolenic acid intake was lower. Such results can be attributed to differences in composition and FA profile of the ingredients of the diets of these studies.

The inclusion of Flemingia in the diet influenced the contents of nonconjugated (e.g., cis-9, trans-12 C18:2) and conjugated isomers (cis-9, trans-11
CLA, trans-10, cis-12 CLA and trans-9, cis11 CLA) of linoleic acid in milk fat (Table 5). These C18:2 FA isomers are some of the various intermediates of the ruminal $\mathrm{BH}$ of linoleic and $\alpha$-linolenic acids, with the main one being rumenic acid or cis-9, trans-11 CLA (SHINGFIELD et al., 2010; LEE; JENKINS, 2011), a compound to which anticarcinogenic, antidiabetogenic (type 2 diabetes), antiatherogenic and immunomodulatory properties have been attributed (KOBA; YANAGITA, 2014; YANG et al., 2015). A linear increase $(\mathrm{P}<0.0001)$ was observed in the rumenic acid milk fat content (Table 5), with an increase of more than $60 \%$ occurring between the diets with inclusion of 0 and $320 \mathrm{~g} \mathrm{~kg}^{-1}$ Flemingia hay. Because of its relevance to human health, the enrichment of milk and dairy products with rumenic acid has been the subject of several studies. 
Table 5. Milk fatty acid composition of Saanen x Boer goats fed diets containing increasing levels of Flemingia hay.

\begin{tabular}{|c|c|c|c|c|c|c|c|c|}
\hline \multirow{2}{*}{$\begin{array}{r}\text { Fatty acid - FA } \\
\left(\mathrm{g} 100 \mathrm{~g}^{-1} \mathrm{FA}\right)\end{array}$} & \multicolumn{5}{|c|}{ Flemingia hay ( $\mathrm{g} \mathrm{kg}^{-1}$ dry matter) } & \multirow[b]{2}{*}{$\mathrm{SEM}^{1}$} & \multicolumn{2}{|c|}{ P-value } \\
\hline & 0 & 80 & 160 & 240 & 320 & & Linear & Quadratic \\
\hline \multicolumn{9}{|c|}{ Linear even-chain saturated fatty acids - LESFA } \\
\hline$\Sigma$ LESFA $4 \leq \mathrm{C} \leq 10$ & 18.25 & 16.69 & 16.26 & 17.44 & 16.83 & 0.6744 & 0.1055 & 0.0287 \\
\hline C12:0 & 4.43 & 4.00 & 3.70 & 3.91 & 3.62 & 0.2894 & 0.0131 & 0.2797 \\
\hline C14:0 & 11.94 & 11.92 & 11.23 & 11.54 & 11.02 & 0.5933 & 0.0220 & 0.9895 \\
\hline $\mathrm{C} 16: 0$ & 30.23 & 30.39 & 28.87 & 30.63 & 28.83 & 0.9746 & 0.2473 & 0.8078 \\
\hline$\Sigma$ LESFA $12 \leq \mathrm{C} \leq 16$ & 46.60 & 46.31 & 43.80 & 46.08 & 43.47 & 1.0348 & 0.0493 & 0.9668 \\
\hline C18:0 & 6.36 & 6.62 & 6.90 & 6.04 & 7.23 & 0.6505 & 0.2601 & 0.5606 \\
\hline C20:0 & 0.139 & 0.154 & 0.173 & 0.146 & 0.172 & 0.0155 & 0.1165 & 0.5760 \\
\hline $\mathrm{C} 22: 0$ & 0.040 & 0.054 & 0.058 & 0.061 & 0.062 & 0.0113 & 0.1033 & 0.4511 \\
\hline $\mathrm{C} 24: 0$ & 0.013 & 0.018 & 0.012 & 0.009 & 0.016 & 0.0037 & 0.7867 & 0.5868 \\
\hline$\Sigma$ LESFA $\geq 18 \mathrm{C}$ & 6.55 & 6.84 & 7.15 & 6.26 & 7.48 & 0.6595 & 0.2352 & 0.5956 \\
\hline \multicolumn{9}{|c|}{ Odd- and branched-chain fatty acids - OBCFA } \\
\hline C11:0 & 0.37 & 0.33 & 0.31 & 0.33 & 0.31 & 0.0245 & 0.0519 & 0.2156 \\
\hline $\mathrm{C} 13: 0$ & 0.111 & 0.098 & 0.094 & 0.098 & 0.087 & 0.0122 & 0.1119 & 0.7524 \\
\hline iso $\mathrm{C} 14: 0$ & 0.093 & 0.129 & 0.138 & 0.122 & 0.109 & 0.0114 & 0.5004 & 0.0098 \\
\hline iso $\mathrm{C} 15: 0$ & 0.164 & 0.155 & 0.160 & 0.164 & 0.145 & 0.0177 & 0.4593 & 0.6237 \\
\hline anteiso $\mathrm{C} 15: 0$ & 0.37 & 0.37 & 0.43 & 0.35 & 0.39 & 0.0330 & 0.8736 & 0.6036 \\
\hline $\mathrm{C} 15: 0$ & 0.69 & 0.67 & 0.81 & 0.66 & 0.75 & 0.0535 & 0.3730 & 0.6655 \\
\hline iso $\mathrm{C} 16: 0$ & 0.27 & 0.31 & 0.30 & 0.27 & 0.33 & 0.0373 & 0.4453 & 0.7992 \\
\hline iso $\mathrm{C} 17: 0$ & 0.24 & 0.21 & 0.23 & 0.21 & 0.23 & 0.0189 & 0.4239 & 0.2633 \\
\hline anteiso $\mathrm{C} 17: 0$ & 0.43 & 0.43 & 0.45 & 0.39 & 0.44 & 0.0252 & 0.7100 & 0.7623 \\
\hline $\mathrm{C} 17: 0$ & 0.36 & 0.35 & 0.40 & 0.36 & 0.39 & 0.0258 & 0.2213 & 0.8565 \\
\hline cis-9 C17:1 & 0.137 & 0.154 & 0.160 & 0.145 & 0.149 & 0.0139 & 0.6295 & 0.2025 \\
\hline $\mathrm{C} 21: 0$ & 0.025 & 0.030 & 0.031 & 0.034 & 0.033 & 0.0040 & 0.1129 & 0.5060 \\
\hline $\mathrm{C} 23: 0$ & 0.013 & 0.015 & 0.019 & 0.023 & 0.020 & 0.0038 & 0.0674 & 0.5234 \\
\hline$\Sigma$ odd- linear-chain FA & 2.92 & 2.87 & 3.25 & 2.89 & 3.08 & 0.1572 & 0.3081 & 0.6210 \\
\hline$\Sigma$ anteiso FA & 0.80 & 0.80 & 0.87 & 0.74 & 0.82 & 0.0550 & 0.9634 & 0.8191 \\
\hline$\Sigma$ iso FA & 0.77 & 0.81 & 0.83 & 0.76 & 0.82 & 0.0524 & 0.7534 & 0.7086 \\
\hline$\Sigma$ OBCFA & 4.49 & 4.47 & 4.95 & 4.39 & 4.72 & 0.2363 & 0.4735 & 0.7080 \\
\hline \multicolumn{9}{|c|}{ cis-even-chain monounsaturated fatty acids } \\
\hline cis-9 C14:1 & 0.171 & 0.172 & 0.159 & 0.162 & 0.146 & 0.0234 & 0.0737 & 0.5895 \\
\hline cis-9 C16:1 & 0.54 & 0.54 & 0.58 & 0.52 & 0.56 & 0.0504 & 0.9303 & 0.7426 \\
\hline cis-9 C18:1 & 16.60 & 17.98 & 19.38 & 17.25 & 18.85 & 0.9418 & 0.1225 & 0.2692 \\
\hline cis-11 C18:1 & 0.68 & 0.74 & 0.83 & 0.78 & 0.84 & 0.0474 & 0.0089 & 0.3255 \\
\hline cis-12 C18:1 & 0.196 & 0.188 & 0.239 & 0.219 & 0.210 & 0.0187 & 0.3027 & 0.2752 \\
\hline cis-13 C18:1 & 0.076 & 0.077 & 0.074 & 0.088 & 0.066 & 0.0103 & 0.7563 & 0.3910 \\
\hline cis-9 C20:1 & 0.038 & 0.043 & 0.044 & 0.046 & 0.055 & 0.0073 & 0.0193 & 0.5669 \\
\hline \multicolumn{9}{|l|}{ trans-C18:1 fatty acids } \\
\hline trans-4 C18:1 & 0.022 & 0.022 & 0.025 & 0.023 & 0.031 & 0.0034 & 0.0938 & 0.3229 \\
\hline
\end{tabular}


continuation

\begin{tabular}{|c|c|c|c|c|c|c|c|c|}
\hline trans-5 C18:1 & 0.011 & 0.007 & 0.010 & 0.015 & 0.013 & 0.0022 & 0.0686 & 0.4698 \\
\hline trans 6-8 C18:1 & 0.045 & 0.046 & 0.057 & 0.061 & 0.067 & 0.0053 & 0.0002 & 0.7920 \\
\hline trans-9 C18:1 & 0.102 & 0.122 & 0.135 & 0.126 & 0.157 & 0.0119 & $<0.0001$ & 0.9462 \\
\hline trans-10 C18:1 & 0.115 & 0.135 & 0.161 & 0.158 & 0.161 & 0.0124 & 0.0064 & 0.1570 \\
\hline trans-11 C18:1 & 0.393 & 0.447 & 0.516 & 0.483 & 0.697 & 0.0714 & $<0.0001$ & 0.1492 \\
\hline trans-12 C18:1 & 0.102 & 0.123 & 0.127 & 0.133 & 0.164 & 0.0121 & $<0.0001$ & 0.4343 \\
\hline trans 13-14 C18:1 & 0.158 & 0.164 & 0.193 & 0.186 & 0.183 & 0.0173 & 0.1266 & 0.3177 \\
\hline trans-16 C18:1 & 0.088 & 0.091 & 0.091 & 0.114 & 0.088 & 0.0107 & 0.5221 & 0.3877 \\
\hline$\Sigma$ trans-C18:1 FA & 1.036 & 1.158 & 1.316 & 1.298 & 1.562 & 0.1141 & $<0.0001$ & 0.6649 \\
\hline$[\mathrm{C} 18: 0] /[$ trans-11 C18:1] ratio & 16.91 & 15.50 & 13.53 & 12.63 & 10.85 & 1.2610 & $<0.0001$ & 0.8689 \\
\hline$[\mathrm{C} 18: 0] /[$ trans-10 C18:1] ratio & 55.45 & 49.15 & 43.76 & 38.55 & 45.10 & 3.6684 & 0.0017 & 0.0155 \\
\hline$[\mathrm{C} 18: 0] /[$ trans-9 C18:1] ratio & 63.89 & 53.85 & 52.51 & 47.90 & 46.43 & 4.7815 & $<0.0001$ & 0.1121 \\
\hline \multicolumn{9}{|c|}{ Conjugated (CLA) and nonconjugated (NCLA) isomers of linoleic acid } \\
\hline trans-9, trans-12 C18:2 (NCLA) & 0.013 & 0.017 & 0.018 & 0.039 & 0.018 & 0.0067 & 0.0966 & 0.1820 \\
\hline cis-9, trans-12 C18:2 (NCLA) & 0.020 & 0.023 & 0.028 & 0.037 & 0.026 & 0.0069 & 0.0463 & 0.0979 \\
\hline trans -9 , cis-12 C18:2 (NCLA) & 0.011 & 0.013 & 0.013 & 0.027 & 0.016 & 0.0059 & 0.1953 & 0.5952 \\
\hline$\Sigma \mathrm{NCLA}$ & 0.043 & 0.052 & 0.059 & 0.102 & 0.060 & 0.0165 & 0.0598 & 0.1898 \\
\hline cis-9, cis-12 C18:2( $\omega-6)$ & 1.713 & 1.870 & 2.105 & 1.861 & 2.059 & 0.1644 & 0.1255 & 0.4339 \\
\hline cis-9, trans-11 CLA & 0.279 & 0.324 & 0.385 & 0.359 & 0.453 & 0.0294 & $<0.0001$ & 0.8937 \\
\hline trans-9, cis-11 CLA & 0.039 & 0.047 & 0.066 & 0.086 & 0.056 & 0.0087 & 0.0118 & 0.0250 \\
\hline trans-10, cis-12 CLA & 0.013 & 0.014 & 0.028 & 0.018 & 0.013 & 0.0027 & 0.8122 & 0.0020 \\
\hline \multicolumn{9}{|c|}{ Long-chain polyunsaturated fatty acids } \\
\hline cis-6, cis-9, cis-12 $\gamma-\mathrm{C} 18: 3(\omega-6)$ & 0.016 & 0.014 & 0.014 & 0.017 & 0.013 & 0.0037 & 0.6790 & 0.9483 \\
\hline 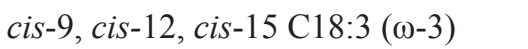 & 0.219 & 0.254 & 0.292 & 0.250 & 0.288 & 0.0269 & 0.1123 & 0.4396 \\
\hline cis-11, cis-14 C20:2 ( $\omega-6)$ & 0.011 & 0.015 & 0.014 & 0.015 & 0.014 & 0.0032 & 0.4633 & 0.5695 \\
\hline cis-8, cis-11, cis-14 C20:3 ( $\omega-6)$ & 0.013 & 0.014 & 0.017 & 0.023 & 0.015 & 0.0045 & 0.3912 & 0.3690 \\
\hline cis-5, cis-8, cis-11, cis-14 C20:4 $\omega-6$ & 0.153 & 0.152 & 0.170 & 0.144 & 0.183 & 0.0196 & 0.1668 & 0.4121 \\
\hline $\mathrm{C} 20: 5 \omega-3 \mathrm{EPA}^{2}$ & 0.041 & 0.041 & 0.047 & 0.038 & 0.046 & 0.0035 & 0.4188 & 0.9257 \\
\hline
\end{tabular}

${ }^{1} \mathrm{SEM}$ - standard error of the mean. ${ }^{2} \mathrm{EPA}$ - eicosapentaenoic acid (cis-5, cis-8, cis-11, cis-14, cis-17 C20:5).

Quadratic effects $(\mathrm{P}<0.05)$ were observed in the trans-10, cis-12 CLA and trans-9, cis-11 CLA milk fat contents in response to increased Flemingia hay in the diet (Table 5). High concentrations of these CLA isomers in milk fat have been associated with mammary lipogenesis inhibition in cows, whereas goats are physiologically less sensitive to their effects (SHINGFIELD et al., 2009, 2010). Although no correlations $(\mathrm{P}>0.05)$ were observed between the fat content or production and the concentrations of these CLAs in goat milk, an inverse relationship ( $\hat{y}$ $\left.=-208.25 \mathrm{x}+65.91 ; \mathrm{r}_{\text {adj }}^{2}=0.24 ; \mathrm{P}=0.0080\right)$ was observed between the trans-10, cis-12 CLA milk fat content ( $\mathrm{g} 100 \mathrm{~g}^{-1} \mathrm{FA}$ ) and the $\mathrm{C} 4: 0$ to $\mathrm{C} 16: 0$ saturated FAs milk concentrations (g $100 \mathrm{~g}^{-1} \mathrm{FA}$ ), originating mostly from de novo FA synthesis in the mammary gland. Such an effect may be associated with inhibition of the abundance of mRNAs and/ or enzymatic activities related to de novo FA synthesis in the mammary gland (ALMEIDA et al., 2013), although Bernard et al. (2009) concluded that reductions of $18 \%$ to $27 \%$ in the secretion of FA synthesized de novo, are not indicative of the occurrence of such changes. Another hypothesis to 
explain the reduction in the content of the de novo FA synthesized in milk is related to the preferential incorporation of mono- and polyunsaturated FA into milk fat triglycerides, since negative correlations ( $\mathrm{r}$ $=-0.40$ to $-0.84 ; \mathrm{P}<0.05)$ were also found between concentrations of FAs synthesized de novo versus the milk fat contents of various unsaturated-C18 FA (e.g., rumenic, linoleic, $\alpha$-linolenic, trans-9 C18:1, trans-10 C18:1, vaccenic, trans-12 C18:1, oleic, cis-11 C18:1, and cis-12 C18:1 FAs).

A linear increase $(\mathrm{P}<0.05)$ was observed in the milk fat contents of C18:1-FAs: cis-11, trans-6-8, trans-9 (elaidic), trans-10, trans-11 (vaccenic) and trans-12 in response to the inclusion of Flemingia hay in the diet (Table 5). These FA, together with cis-10 C18:1, cis-12 to cis-15 C18:1 and trans-13 to trans-16 C18:1, are the major C18:1 isomers formed during the $\mathrm{BH}$ of oleic, linoleic and $\alpha$-linolenic FAs in the rumen (SHINGFIELD et al., 2010; BUCCIONI et al., 2012). Among the trans-C18:1 isomers, we highlight the vaccenic, elaidic and trans-10 C18:1 FAs as the most interesting for human health. The latter two have been associated with deleterious effects on cardiovascular health (ALMEIDA et al., 2014), and therefore, the reduction of their contents in the milk fats is desirable. On the other hand, vaccenic acid, which was the major isomer of trans-C18:1 (Table 5), is responsible for $63 \%$ to $73 \%$ of the total rumenic acid secreted in goat milk via SCD action on the mammary gland (BERNARD et al., 2010). Therefore, diets that promote an increase in the supply of vaccenic acid from the rumen to the mammary gland result in higher rumenic acid milk contents. In addition, $19 \%$ of the ingested vaccenic acid is converted to rumenic acid in human tissues (TURPEINEN et al., 2002). The regression of milk fat contents of rumenic versus vaccenic acids ( $g 100$ $\mathrm{g}^{-1}$ FA) demonstrates the close association between these FAs $\left(\hat{y}=0.16654+0.3816 x ; r^{2}{ }_{\text {adj }}=0.64\right.$; $\mathrm{P}<0.0001$ ), also reported in goat milk by Chilliard and Ferlay (2004) $\left(\hat{\mathrm{y}}=0.15+0.40 \mathrm{x} ; \mathrm{r}^{2}=0.98\right)$.

The accumulation of cis/trans isomers of C18:1 in milk fat content is initially modulated by the ingested lipids associated with its hydrolysis in the rumen, as well as by the ruminal $\mathrm{BH}$ pattern exerted by the resident microbiota on the oleic, linoleic and $\alpha$-linolenic FA released in the hydrolysis process (BUCCIONI et al., 2012). Ruminal acid pH condition (BUCCIONI et al., 2012) or selection of specific microbial populations, induced by the action of ionophores (LOURENÇO et al., 2010) or of secondary compounds (e.g., tannins, saponins, essential oils) present in the diet (PATRA; SAXENA, 2009) may alter the total concentration of the trans-C18:1 isomers, as well as the distribution of these isomers in milk fat. In the present study, no ionophore was used, and the mean values of $\mathrm{pH}$ $(>6.6)$ and rumen concentration of ammonia nitrogen (>11 $\mathrm{mg} \mathrm{dL}^{-1}$ ) presented by Oiticica et al. (2015) can be inferred to allow extensive ruminal $\mathrm{BH}$ of oleic, linoleic and $\alpha$-linolenic acids, to the point of leveling their concentrations in fat milk (Table 5), in spite of the differences $(\mathrm{P}<0.05)$ between the diets on the intake of these FAs (Table 4). At the same time, the significant changes observed in the milk fat contents of the cis/trans C18:1 isomers and the conjugated and nonconjugated isomers of linoleic acid (Table 5) indicate that the dietary inclusion of Flemingia hay substantially modified the pattern and the extent of ruminal $\mathrm{BH}$ of $\mathrm{C} 18$-unsaturated FAs in the rumen. The cis/trans C18:1 FA originates directly from isomerization of the oleic acid in the rumen (MOSLEY et al., 2006), occurring mainly from the action of reductase enzymes synthesized by the microbiota on various conjugated and nonconjugated isomers of linoleic acid, formed on the $\mathrm{BH}$ routes of dietary linoleic and $\alpha$-linolenic acids (LEE; JENKINS, 2011; BUCCIONI et al., 2012). The positive correlations $(\mathrm{P}<0.05)$ observed between the various cis/trans $\mathrm{C} 18: 1$ isomers versus rumenic acid, trans-10, cis-12 CLA or trans-9, cis-11 CLA illustrate the common ruminal $\mathrm{BH}$ routes of these FAs (Table 6). Notably, the positive correlations between the rumenic acid or trans-10, cis-12 CLA versus oleic acid (Table 6) should be interpreted as mathematical artifacts, probably 
resulting from the coelution of oleic acid with

(VASTA et al., 2009a).

trans-15 C18:1 in the FA analysis chromatogram

Table 6. Pearson correlation coefficients between concentrations of conjugated linoleic acid (CLA) and cis/trans-C18:1 isomers in milk fat from Saanen x Boer goats fed diets containing increasing levels of Flemingia hay.

\begin{tabular}{lccccccc}
\hline \multirow{2}{*}{$\begin{array}{l}\text { CLA isomer } \\
\left.\text { ( } 100 \mathrm{~g}^{-1} \text { fatty acid }\right)\end{array}$} & trans-9 & trans-10 & trans-11 & trans-12 & cis-9+trans-15 & cis-11 & cis-12 \\
\hline cis-9, trans -11 & $0.84^{* * *}$ & $0.58^{* *}$ & $0.81^{* * *}$ & $0.67^{* *}$ & $0.41^{*}$ & $0.57^{* *}$ & $\mathrm{NS}^{1}$ \\
trans -10, cis-12 & $\mathrm{NS}$ & $0.47^{*}$ & $\mathrm{NS}$ & $\mathrm{NS}$ & $0.46^{*}$ & $\mathrm{NS}$ & $0.49^{*}$ \\
trans -9, cis -11 & $\mathrm{NS}$ & $0.65^{* *}$ & $\mathrm{NS}$ & $\mathrm{NS}$ & $\mathrm{NS}$ & $\mathrm{NS}$ & $0.49^{*}$ \\
\hline
\end{tabular}

${ }^{1} \mathrm{NS}$ - not significant $(\mathrm{P}>0.05) ;{ }^{*} \mathrm{P}<0.05 ;{ }^{* *} \mathrm{P}<0.01 ;{ }^{* * *} \mathrm{P}<0.0001$.

In spite of the linear increase $(\mathrm{P}<0.05)$ observed in the stearic acid intake (Table 4$)$, the inclusion of Flemingia hay in the diet did not affect $(\mathrm{P}>0.05)$ the concentration of this FA (Table 5), which is the last product of the ruminal $\mathrm{BH}$ of all the $\mathrm{C} 18$-unsaturated FA present in the diet (SHINGFIELD et al., 2010). The milk fat contents of stearic and oleic acids were low (Table 5) when compared to the ranges from

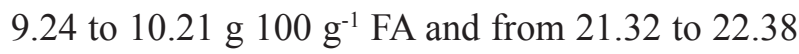
g $100 \mathrm{~g}^{-1}$ FA, respectively, reported by Fagundes (2012) in the milk of Saanen x Boer goats fed diets with 0,125 and $250 \mathrm{~g} \mathrm{~kg}^{-1} \mathrm{DM}$ from Flemingia hay replacing Tifton-85 hay. The inclusion of Flemingia in the diet promoted a linear decrease $(\mathrm{P}<0.0001)$ in the C18:0/trans-11 C18:1 ratio in the milk fat (Table 5), which can be considered indicative of a reduction in the last step of the main $\mathrm{BH}$ route of the linoleic and $\alpha$-linolenic acids in the rumen (VASTA et al., 2009b, 2010). A linear reduction $(\mathrm{P}<0.0001)$ was also observed in the $\mathrm{C} 18: 0 /$ trans $-9 \mathrm{C} 18: 1$ ratio, whereas for the C18:0/trans-10 C18:1 ratio, the inclusion of Flemingia hay into the diet promoted a quadratic effect $(\mathrm{P}<0.05$; Table 5). Previous studies have shown that the addition of CT in the incubation substrate (KHIAOSA-ARD et al., 2009; VASTA et al., 2009a) or in the sheep diet (VASTA et al., 2009b, 2010) promoted an increase in the content of the vaccenic acid in the ruminal fluid. In addition, Vasta et al. (2010) demonstrated that supplementation of the diet of sheep with tannins altered the composition of the cellulolytic bacteria populations involved in the C18-unsaturated FA BH, with an increase in the abundance of Butyrivibrio fibrisolvens, the main species involved in the initial step of ruminal $\mathrm{BH}$ of linoleic acid to rumenic acid, with the vaccenic acid as the major final product; the reduction of Butyrivibrio proteoclasticus, which carries out the final step of BH, converts the vaccenic and trans-10 C18:1 FA into stearic acid in the rumen (McKAIN et al., 2010).

In the present study, due to analytical problems, determination of the tannin content in Flemingia hay and in the experimental diets was not possible. However, Fagundes et al. (2014) reported a high CT content (10.5 $\left.\mathrm{g} \mathrm{kg}^{-1} \mathrm{DM}\right)$ in Flemingia hay produced in the same experimental area, also cut in the dry season (July 2010), with similar height $(1.2 \mathrm{~m})$ to the one used in the present study. From this information, it may be assumed that the CT present in the Flemingia hay may have selectively modulated the cellulolytic bacterial population of the goat rumen in favor of group A bacteria (e.g., B. fibrisolvens), which isomerize and hydrogenate linoleic acid to vaccenic acid, to the detriment of those of bacteria of group B (e.g., B. proteoclasticus), which hydrogenate the vaccenic and trans-10 C18:1 FA to stearic acid (VASTA et al., 2009b). Positive correlations between trans-10, cis-12 CLA with trans-10 C18:1 and cis-12 C18:1 (Table 6) indicate that these FAs were important $\mathrm{BH}$ intermediates of 
this CLA isomer in the rumen, corroborating the in vitro results reported by McKain et al. (2010), which demonstrated that $B$. fibrisolvens JW11 metabolized trans-10, cis-12 CLA in trans-10 C18:1, trans-12 C18:1 and cis-12 C18:1. McKain et al. (2010) also demonstrated that the bacterium Propionibacterium acnes does not metabolize geometric isomers of CLA but specializes in isomerizing linoleic acid for trans-10, cis-12 CLA and can metabolize trans-10 C18:1 and oleic acid. The quadratic effect $(\mathrm{P}<0.05)$ observed in the content of the trans-10, cis-12 CLA in milk fat and in the $\mathrm{C} 18: 0 /$ trans-10 $\mathrm{C} 18: 1$ ratio (Table 5) may have been due to the increase in $B$. fibrisolvens and $P$. acnes populations in the rumen of goats and by the different roles of these bacteria in BH. Furthermore, assuming that the quadratic effect $(\mathrm{P}<0.05)$ in the trans-10, cis-12 CLA milk fat content (Table 5) reflected the concentration in the rumen of the goats, possibly, this situation may have contributed to the reduction of the B. proteoclasticus population, since McKain et al. (2010) observed that the P-18 line of this bacterium did not grow in medium with this CLA isomer.

No effect $(\mathrm{P}>0.05)$ of inclusion of Flemingia hay on the diet was observed on the milk odd- and branched-chain fatty acids (OBCFA) content (Table 5). The prevailing OBCFAs in milk fat were $C 15: 0$, $\mathrm{C} 17: 0$, anteiso $\mathrm{C} 15: 0$ and anteiso $\mathrm{C} 17: 0$, as also observed by Cívico et al. (2017). OBCFAs originate, for the most part, from the FAs synthesized de novo and incorporated into the cell membrane of ruminal bacteria, so that the concentrations of these FA in milk fat may be indicative of the activity and growth of classes of bacteria in the rumen (VLAEMINCK et al., 2006; CÍVICO et al., 2017).
Thus, the inclusion of Flemingia hay in the diet allowed stability in the populations of amylolytic and cellulolytic bacteria, although the possibility of some alteration in the relative proportions of the cellulolytic species, which cannot be predicted on the basis in the concentrations of OBCFA in milk fat, should not be discounted.

No effect $(\mathrm{P}>0.05)$ of the inclusion of Flemingia hay on the diet was observed in the apparent transfer of ingested linoleic acid into the milk (Table 7). This result is another indicator of the extensive $\mathrm{BH}$ of this substrate in the rumen, especially if we consider the linear increase $(\mathrm{P}<0.05)$ in its intake in the diets with higher proportions of Flemingia hay (Table 4). On the other hand, even if the inclusion of Flemingia hay in the diet of goats promoted a linear reduction $(\mathrm{P}<0.05)$ in $\alpha$-linolenic acid intake (Table 4), a linear increase was observed $(\mathrm{P}<0.05)$ in the apparent transfer of this FA from the diet into the milk (Table 7), indicating that a fraction of the $\alpha$-linolenic acid consumed did not undergo $\mathrm{BH}$ in the rumen. This may explain, at least in part, the unexpected inverse relation between the rumenic acid milk fat content (g $\left.100 \mathrm{~g}^{-1} \mathrm{FA}\right)$ and the $\alpha$-linolenic acid intake $\left(\mathrm{g} \mathrm{d}^{-1}\right)$ $\left(\hat{y}=0.63343-0.13501 x ; r^{2}{ }_{\text {adj }}=0.23 ; \mathrm{P}=0.0084\right)$. The apparent protection of the ruminal $\mathrm{BH}$ of the ingested $\alpha$-linolenic acid has been associated with the presence of CT in the forage consumed (ROY et al., 2002) and with the polyphenol oxidase enzyme activity on endogenous and ruminal lipolysis (LEE et al., 2008; BUCCIONI et al., 2012; LEE, 2014). In a study conducted with cows receiving a diet with forage rich in tannins, Kälber et al. (2011) reported a high transfer of ingested $\alpha$-linolenic acid into milk. 
Table 7. Secretion of fatty acids in milk from Saanen x Boer goats fed diets containing increasing levels of Flemingia hay.

\begin{tabular}{|c|c|c|c|c|c|c|c|c|}
\hline \multirow{2}{*}{ Fatty acid - FA $\left(\mathrm{g} \mathrm{d}^{-1}\right)$} & \multicolumn{5}{|c|}{ Flemingia hay ( $\mathrm{g} \mathrm{kg}^{-1}$ dry matter) } & \multirow[b]{2}{*}{$\mathrm{SEM}^{1}$} & \multicolumn{2}{|l|}{ P-value } \\
\hline & 0 & 80 & 160 & 240 & 320 & & Linear & Quadratic \\
\hline$\Sigma$ FA $4 \leq \mathrm{C} \leq 10$ & 9.65 & 7.99 & 7.48 & 8.10 & 9.05 & 1.8446 & 0.3986 & 0.0116 \\
\hline $\mathrm{C} 12: 0$ & 1.79 & 1.52 & 1.39 & 1.49 & 1.55 & 0.3001 & 0.0545 & 0.0132 \\
\hline $\mathrm{C} 14: 0$ & 4.93 & 4.48 & 4.10 & 4.24 & 4.66 & 0.7779 & 0.2416 & 0.0321 \\
\hline C16:0 & 13.09 & 11.77 & 10.66 & 11.36 & 12.89 & 2.7241 & 0.6732 & 0.0666 \\
\hline$\Sigma$ FA $12 \leq \mathrm{C} \leq 16$ & 19.82 & 17.77 & 16.14 & 17.09 & 19.11 & 3.7430 & 0.4179 & 0.0413 \\
\hline $\mathrm{C} 18: 0$ & 2.94 & 2.65 & 2.53 & 2.25 & 3.37 & 0.7664 & 0.4706 & 0.0834 \\
\hline trans-9 C18:1 & 0.043 & 0.048 & 0.047 & 0.046 & 0.072 & 0.0121 & 0.0154 & 0.1036 \\
\hline trans-10 C18:1 & 0.051 & 0.053 & 0.057 & 0.059 & 0.073 & 0.0135 & 0.0254 & 0.4390 \\
\hline trans-11 C18:1 & 0.172 & 0.180 & 0.185 & 0.179 & 0.324 & 0.0583 & 0.0048 & 0.0365 \\
\hline cis-9 C18:1 & 7.17 & 6.88 & 6.90 & 6.24 & 8.20 & 1.4446 & 0.2733 & 0.2873 \\
\hline cis-9, cis-12 C18:2 & 0.71 & 0.73 & 0.74 & 0.69 & 0.87 & 0.1425 & 0.1973 & 0.4146 \\
\hline cis-9, cis-12, cis-15 C18:3 & 0.097 & 0.098 & 0.104 & 0.096 & 0.126 & 0.0243 & 0.1835 & 0.4069 \\
\hline cis-9, trans-11 CLA & 0.117 & 0.125 & 0.134 & 0.132 & 0.201 & 0.0298 & 0.0030 & 0.0915 \\
\hline trans-9, cis-11 CLA & 0.014 & 0.019 & 0.023 & 0.030 & 0.026 & 0.0046 & 0.0072 & 0.2931 \\
\hline trans-10, cis-12 CLA & 0.005 & 0.006 & 0.010 & 0.006 & 0.006 & 0.0015 & 0.6027 & 0.1083 \\
\hline $\mathrm{C} 20: 5 \omega-3 \mathrm{EPA}^{2}$ & 0.017 & 0.016 & 0.017 & 0.014 & 0.020 & 0.0035 & 0.5606 & 0.1396 \\
\hline Odd- and branched-chain FA & 1.92 & 1.73 & 1.73 & 1.67 & 2.04 & 0.3740 & 0.6828 & 0.1306 \\
\hline \multicolumn{9}{|c|}{ Apparent transfer of ingested poly-unsaturated FA $\left(\mathrm{g} \mathrm{d}^{-1}\right)$ into milk $\left(\mathrm{g} \mathrm{d}^{-1}\right)$} \\
\hline cis-9, cis-12 C18:2 & 0.041 & 0.038 & 0.036 & 0.032 & 0.041 & 0.0074 & 0.7029 & 0.2494 \\
\hline cis- 9, cis-12, cis-15 C18:3 & 0.046 & 0.046 & 0.049 & 0.049 & 0.072 & 0.0118 & 0.0315 & 0.1377 \\
\hline
\end{tabular}

${ }^{1} \mathrm{SEM}$ - standard error of the mean. ${ }^{2} \mathrm{EPA}$ - eicosapentaenoic acid (cis-5, cis-8, cis-11, cis-14, cis-17 C20:5).

Negative correlations $(\mathrm{P}<0.05)$ were observed between the contents of vaccenic acid or trans-12 C18:1 milk fat versus SCD activity index for cis9 C14:1/C14:0 and oleic/stearic pairs of FAs. Notably, the cis-9 C14:1/14:0 ratio is considered the best indicator of SCD activity in the mammary gland (BERNARD et al., 2010). Bernard et al. (2009) reported a higher sensitivity of SCD in the mammary gland of goats compared to that of cows for the inhibitory effects of polyunsaturated FAs and intermediates of ruminal $\mathrm{BH}$. No correlation $(\mathrm{P}>0.05)$ was observed between the contents of the three isomers of CLA and the other trans-C18:1 isomers with the indexes of SCD activity.

A positive correlation was observed between stearic acid versus milk fat content $(\mathrm{r}=0.60 ; \mathrm{P}=$ 0.0016 ), corroborating the value of this correlation
( $r=0.61)$ presented by Bernard et al. (2015) and the hypothesis discussed by Chilliard and Ferlay (2004) that stearic acid is the main regulator of lipogenesis in the mammary gland of goats. The lower production of stearic acid in the rumen, as a function of the reduction in the last ruminal $\mathrm{BH}$ step, as indicated by the $\mathrm{C} 18: 0 /$ trans-11 $\mathrm{C} 18: 1$ ratio (Table 5), may have reduced the availability of stearic acid for uptake by the mammary gland for its desaturation and subsequent esterification of the oleic acid at the $s n-3$ position of triacylglycerol, an important mechanism in the control of the melting point and fluidity of milk fat (BERNARD et al., 2015; TORAL et al., 2015).

Negative correlations $(\mathrm{P}<0.05)$ were observed between the SCD activity indexes (cis-9 C14:1/ C14:0, oleic/stearic and rumenic/vaccenic pairs) 
with the content ( $r=-0.57$ to -0.67$)$ and the milk fat production ( $\mathrm{r}=-0.49$ to -0.54$)$. In this way, the quadratic effects $(\mathrm{P}<0.05)$ observed for fat and FCM production (Table 3) can be inferred to be related to the activities of the oleic/stearic and rumenic/vaccenic pairs of the SCD enzyme (Table 8). Because stearic acid is the preferred substrate for the SCD enzyme (SHINGFIELD et al., 2010), its putative lower availability to the mammary gland indirectly impaired the secretion of rumenic acid, since it reduced the activity of SCD in vaccenic acid desaturation $\left(\hat{y}=-0.07901 x+1.26696 ; r^{2}{ }_{\text {adj }}=0.53\right.$; $\mathrm{P}=0.0269$ ), as indicated by the inverse relationship $\left(\hat{y}=-0.07901 x+1.26696 ; r^{2}{ }_{\text {adj }}=0.53 ; \mathrm{P}<0.0001\right)$ observed between the stearic acid milk fat content (g $100 \mathrm{~g}^{-1} \mathrm{FA}$ ) and the rumenic/vaccenic ratio.

Table 8. Milk fat desaturase indexes from Saanen x Boer goats fed diets containing increasing levels of Flemingia hay.

\begin{tabular}{lcccccccc}
\hline & \multicolumn{4}{c}{ Flemingia hay $\left(\mathrm{g} \mathrm{kg}^{-1}\right.$ dry matter $)$} & & \multicolumn{2}{c}{ P-value } \\
\cline { 2 - 5 } Index $^{1}$ & 0 & 80 & 160 & 240 & 320 & SEM $^{2}$ & Linear & Quadratic \\
\hline cis-9 C14:1/C14:0 & 0.0139 & 0.0141 & 0.0140 & 0.0135 & 0.0128 & 0.0014 & 0.1403 & 0.3324 \\
cis-9 C16:1/C16:0 & 0.0176 & 0.0175 & 0.0198 & 0.0168 & 0.0189 & 0.0016 & 0.3420 & 0.7067 \\
oleic/stearic & 0.7252 & 0.7310 & 0.7373 & 0.7406 & 0.7235 & 0.0215 & 0.7457 & 0.0444 \\
rumenic/vaccenic & 0.4206 & 0.4280 & 0.4280 & 0.4307 & 0.4047 & 0.0229 & 0.2544 & 0.0454 \\
\hline
\end{tabular}

${ }^{1}$ Values represent the ratio of product / (substrate + product) for Stearoyl-CoA desaturase enzyme. ${ }^{2}$ SEM - standard error of the mean.

In general, the secretion of most FA (Table 7) followed the pattern of the observed results for their milk fat contents (Table 5), except for secretions of lauric, myristic, trans-9, cis-11 CLA and trans-10, cis-12 CLA (Table 7), whose effects resulting from the inclusion of Flemingia hay in the diet were more strongly impacted by the quadratic effect $(\mathrm{P}<0.05)$ observed for milk fat production (Table 3 ). The lowest secretions of lauric and myristic acids and their sum with palmitic acid were 1.41, 4.15 and $16.44 \mathrm{~g} \mathrm{~d}^{-1}$, respectively, estimated for the inclusion of Flemingia in the diet at 191, 179 and $171 \mathrm{~g} \mathrm{~kg}^{-1}$ DM. The linear increases observed $(\mathrm{P}<0.05)$ in the contents and secretions of rumenic and vaccenic acids as the Flemingia hay was added to the diet are positive for human health. However, the milk fat contents and milk secretions of elaidic and trans -10 C18:1 FA, whose consumption has been associated with deleterious effects on cardiovascular health (ALMEIDA et al., 2014), also increased linearly $(\mathrm{P}<0.05)$.

The linear reduction $(\mathrm{P}<0.05)$ observed in AI (Table 9) shows that as Flemingia hay was added to the diet an improvement occurred in the nutritional quality of the milk fat. This result was mainly a consequence of the decreases $(\mathrm{P}<0.05)$ observed in the milk fat contents of lauric and myristic acids, considered hypercholesterolemic (FAO, 2010), since the inclusion of Flemingia in the diet did not affect $(\mathrm{P}>0.05)$ the concentration of oleic acid (Table 5) and the milk fat contents of sum of $\omega-6$ and of sum of $\omega-3$ FAs (Table 9). 
Table 9. Indices of the nutritional quality of milk fat from Saanen x Boer goats fed diets containing increasing levels of Flemingia hay.

\begin{tabular}{|c|c|c|c|c|c|c|c|c|}
\hline \multirow{2}{*}{ Index } & \multicolumn{5}{|c|}{$\begin{array}{c}\text { Flemingia hay } \\
\left(\mathrm{g} \mathrm{kg}^{-1} \text { dry matter }\right)\end{array}$} & \multirow[b]{2}{*}{ SEM $^{1}$} & \multicolumn{2}{|c|}{ P-value } \\
\hline & 0 & 80 & 160 & 240 & 320 & & Linear & Quadratic \\
\hline Atherogenicity index & 4.49 & 4.08 & 3.55 & 4.15 & 3.59 & 0.2639 & 0.0355 & 0.3713 \\
\hline Thrombogenicity index & 4.68 & 4.22 & 3.68 & 4.37 & 3.74 & 0.2709 & 0.0526 & 0.4003 \\
\hline $\begin{array}{l}\text { Hypo:hypercholesterolemic } \\
\text { fatty acids ratio }\end{array}$ & 0.36 & 0.40 & 0.45 & 0.38 & 0.44 & 0.0258 & 0.0827 & 0.4455 \\
\hline$\Sigma$ cis $\omega-3$ fatty acids & 0.26 & 0.29 & 0.34 & 0.29 & 0.33 & 0.0277 & 0.1059 & 0.4519 \\
\hline$\Sigma$ cis $\omega-6$ fatty acids & 1.91 & 2.06 & 2.32 & 2.06 & 2.28 & 0.1789 & 0.1099 & 0.4705 \\
\hline$\omega-6: \omega-3$ fatty acids ratio & 7.42 & 6.99 & 7.03 & 7.24 & 6.92 & 0.5393 & 0.5113 & 0.7853 \\
\hline
\end{tabular}

${ }^{1} \mathrm{SEM}$ - standard error of the mean.

\section{Conclusions}

The inclusion of up to $320 \mathrm{~g} \mathrm{~kg}^{-1}$ of Flemingia macrophylla hay in the dry matter of Saanen $\mathrm{x}$ Boer goat diets in replacement of the Tifton- 85 hay does not modify the milk production and allows milk fat to be produced with more adequate nutritional quality for human consumption, with higher levels of rumenic and vaccenic acids, beneficial to health, and with lower concentrations of hypercholesterolemic fatty acids.

\section{Acknowledgments}

We acknowledge Capes for the grant of the scholarship. We thank the technicians in the Laboratory of Chromatography of Embrapa Dairy Cattle, Ernando Ferreira Motta and Hernani Guilherme Barbosa Filho, who were responsible for the fatty acid analysis.

\section{References}

ALMEIDA, M. M.; LUQUETTI, S. C. D.; SABARENSE, C. M.; CORRÊA, J. O. A.; REIS, L. G.; CONCEIÇÃO, E. P. S.; LISBOA, P. C.; MOURA, E. G.; GAMEIRO, J.; GAMA, M. A. S.; LOPES, F. C. F.; GONZÁLEZ GARCIA, R. M. Butter naturally enriched in cis-9 trans-11 CLA prevents hyperinsulinemia and increases both serum HDL cholesterol and triacylglycerol levels in rats. Lipids in Health and Disease, London, v. 13, n. 200, p. 1-13, 2014.

ALMEIDA, O. C.; PIRES, A. V.; SUSIN, I.; GENTIL, R. S.; MENDES, C. Q.; QUEIROZ, M. A. A.; FERREIRA, E. M.; EASTRIDGE, M. L. Milk fatty acids profile and arterial blood milk fat precursors concentration of dairy goats fed increasing doses of soybean oil. Small Ruminant Research, Amsterdan, v. 114, n. 1, p. 152-160, 2013.

ANDERSSON, M. S.; LASCANO, C. E.; SCHULTZEKRAFT, R.; PETERS, M. Forage quality and tannin concentration and composition of a collection of the tropical shrub legume Flemingia macrophylla. Journal of Science and Food Agricultural, Oxford, v. 86, n. 7, p. 1023-1031, 2006.

ANDERSSON, M. S.; SCHULTZE-KRAFT, R.; PETERS, M. Flemingia macrophylla (Willd.) Merrill. Rome: FAO Grassland Index, 2002. Available at: $<$ http://www.fao.org/ag/AGP/AGPC/doc/GBASE/ data/ pf000154.htm>. Accessed at: 24 aug. 2017.

BARAHONA, R.; LASCANO, C. E.; COCHRAN, R.; MORRILL, J.; TITGEMEYER, E. C. Intake, digestion, and nitrogen utilization by sheep fed tropical legumes with contrasting tannin concentration and astringency. Journal of Animal Science, Champaign, v. 75, n. 6, p. 1633-1640, 1997.

BERNARD, L.; LEROUX, C.; FAULCONNIER, Y.; DURAND, D.; SHINGFIELD, K. J.; CHILLIARD, Y. Effect of sunflower-seed oil or linseed oil on milk fatty acid secretion and lipogenic gene expression in goats fed hay-based diets. Journal of Dairy Research, Cambridge, v. 76, n. 2, p. 241-248, 2009. 
BERNARD, L.; LEROUX, C.; ROUEL, J.; DELAVAUD, C.; SHINGFIELD, K. J.; CHILLIARD, Y. Effect of extruded linseeds alone or in combination with fish oil on intake, milk production, plasma metabolite concentrations and milk fatty acid composition in lactating goats. Animal, Cambridge, v. 9, n. 5, p. 810821, 2015.

BERNARD, L.; MOURIOT, J.; ROUEL, J.; GLASSER, F.; CAPITAN, P.; PUJOS-GUILLOT, E.; CHARDIGNY, J.-M.; CHILLIARD, Y. Effects of fish oil and starch added to a diet containing sunflower-seed oil on dairy goat performance, milk fatty acid composition and in vivo $\Delta 9$-desaturation of $\left[{ }^{13} \mathrm{C}\right]$ vaccenic acid. British Journal of Nutrition, Cambridge, v. 104, n. 3, p. 346-354, 2010.

BUCCIONI, A.; DECANDIA, M.; MINIERI, S.; MOLLE, G.; CABIDDU, A. Lipid metabolism in the rumen: New insights on lipolysis and biohydrogenation with an emphasis on the role of endogenous plant factors. Animal Feed Science and Technology, Amsterdan, v. 174, n. 1-2, p. 1-25, 2012.

CHILLIARD, Y.; FERLAY, A. Dietary lipids and forages interactions on cow and goat milk fatty acid composition and sensory properties. Reproduction Nutrition Development, Cambridge, v. 44, n. 5, p. 467-492, 2004.

CÍVICO, A.; SÁNCHEZ, N. N.; GÓMEZ-CORTÉS, P.; de la FUENTE, M. A.; BLANCO, F. P.; JUÁREZ, M.; SCHIAVONE, A.; MARTÍNEZ MARÍN, A. L. Odd- and branched-chain fatty acids in goat milk as indicators of the diet composition. Italian Journal of Animal Science, Abingdon, v. 16, n. 1, p. 68-74, 2017.

FAGUNDES, G. M. Desempenho produtivo e composição do leite de cabras alimentadas com dietas contendo diferentes niveis de Flemingia macrophylla (willd.) Merrill com e sem Polietilenoglicol. 2012. Dissertação (Mestrado em Ciências) - Universidade Federal Rural do Rio de Janeiro, Seropédica.

FAGUNDES, G. M.; MODESTO, E. C.; FONSECA, C. E. M.; LIMA, H. R. P.; MUIR, J. P. Intake, digestibility and milk yield in goats fed Flemingia macrophylla with or without polyethylene glycol. Small Ruminant Research, Amsterdan, v. 116, n. 2-3, p. 88-93, 2014.

FOOD AND AGRICULTURE ORGANIZATION OF THE UNITED NATIONS - FAO. Fats and fatty acids in human nutrition. Report of an expert consultation. Roma: FAO, 2010. 166 p.

JACKSON, F. S.; BARRY, T. N.; LASCANO, C.; PALMER, B. The extractable and bound condensed tannin content of leaves from tropical tree, shrub and forage legumes. Journal of the Science of Food and Agriculture, Oxford, v. 71, n. 1, p. 103-110, 1996.
KÄLBER, T.; MEIER, J. S.; KREUZER, M.; LEIBER, F. Flowering catch crops used as forage plants for dairy cows: influence on fatty acids and tocopherols in milk. Journal of Dairy Science, Champaign, v. 94, n. 3, p. 1477-1489, 2011.

KEXIAN, Y.; LASCANO, C. E.; KERRIDGE, P. C.; AVILA, P. The effect of three tropical shrub legumes on intake rate and acceptability by small ruminants. Pasturas Tropicales, Cali, v. 20, n. 3, p. 31-35, 1998.

KHIAOSA-ARD, R.; BRYNER, S. F.; SCHEEDER, M. R. L.; WETTSTEIN, H.-R.; LEIBER, F.; KREUZER, M.; SOLIVA, C. R. Evidence for the inhibition of the terminal step of ruminal $\alpha$-linolenic acid biohydrogenation by condensed tannins. Journal of Dairy Science, Champaign, v. 92, n. 1, p. 177-188, 2009.

KOBA, K.; YANAGITA, T. Health benefits of conjugated linoleic acid (CLA). Obesity Research \& Clinical Practice, Amsterdan, v. 8, n. 6, p. e525-e532, 2014.

LEE, M. R. F. Forage polyphenol oxidase and ruminant livestock nutrition. Frontiers in Plant Science, Lausanne, v. 5, Article 694, p. 1-9, 2014.

LEE, M. R. F.; TWEED, J. K. S.; SCOLLAN, N. D.; SULLIVAN, M. L. Ruminal micro-organisms do not adapt to increase utilization of poly-phenol oxidase protected red clover protein and glycerol-based lipid. Journal of Science and Food Agricultural, Oxford, v. 88, n. 14, p. 2479-2485, 2008.

LEE, Y.-J.; JENKINS, T. C. Biohydrogenation of linolenic acid to stearic acid by the rumen microbial population yields multiple intermediate conjugated diene isomers. Journal of Nutrition, Cambridge, v. 141, n. 8, p. 1445-1450, 2011.

LOURENÇO, M.; RAMOS-MORALES, E.; WALLACE, R. J. The role of microbes in rumen lipolysis and biohydrogenation and their manipulation. Animal, Cambridge, v. 4, n. 7, p. 1008-1023, 2010.

MARTÍNEZ MARÍN, A. L.; GÓMEZ-CORTÉS, P.; GÓMEZ CASTRO, A. G.; JUÁREZ, M.; PÉREZ ALBA, L. M.; PÉREZ HERNÁNDEZ, M.; de la FUENTE, M. A. Animal performance and milk fatty acid profile of dairy goats fed diets with different unsaturated plant oils. Journal of Dairy Science, Champaign, v. 94, n. 11, p. 5359-5368, 2011.

MARTÍNEZ MARÍN, A. L.; GÓMEZ-CORTÉS, P.; GÓMEZ CASTRO, G.; JUÁREZ, M.; PÉREZ ALBA, L.; PÉREZ HERNÁNDEZ, M.; de la FUENTE, M. A. Effects of feeding increasing dietary levels of high oleic or regular sunflower or linseed oil on fatty acid profile of goat milk. Journal of Dairy Science, Champaign, v. 95, n. 4, p. 1942-1955, 2012. 
McKAIN, N.; SHINGFIELD, K. J.; WALLACE, R. J. Metabolism of conjugated linoleic acids and 18:1 fatty acids by ruminal bacteria: products and mechanisms. Microbiology, London, v. 156, n. 2, p. 579-588, 2010.

MOSLEY, E. E.; NUDDA, A.; CORATO, A.; ROSSI, E.; JENKINS, T.; McGUIRE, M. A. Differential biohydrogenation and isomerization of $\left[\mathrm{U}-{ }^{13} \mathrm{C}\right] \mathrm{Oleic}$ and $\left[1-{ }^{13} \mathrm{C}\right]$ Oleic acids by mixed ruminal microbes. Lipids, Oxford, v. 41, n. 5, p. 513-517, 2006.

MOURTHÉ, M. H. F.; REIS, R. B.; GAMA, M. A. S.; BARROS, P. A. V.; ANTONIASSI, R.; BIZZO, H. R.; LOPES, F. C. F. Milk fatty acid profile of Holstein $x$ Gyr cows grazing on marandugrass supplemented with increasing levels of roasted soybeans. Arquivo Brasileiro de Medicina Veterinária e Zootecnia, Belo Horizonte, v. 67, n. 8, p. 1150-1158, 2015.

MUI, N. T.; LEDIN, I.; UDÉN, P.; VAN BINH, D. Effect of replacing a rice bran-soya bean concentrate with Jackfruit (Artocarpus heterophyllus) or Flemingia (Flemingia macrophylla) foliage on the performance of growing goats. Livestock Production Science, Amsterdan, v. 72, n. 3, p. 253-262, 2001.

OITICICA, I. N.; FONSECA, C. E. M.; SOUZA, V. C.; SILVA, A. B.; LOPES, F. C. F.; MORENZ, M. J. F. Flemingia macrophylla in goat feeding. Revista Brasileira de Zootecnia, Viçosa, MG, v. 44, n. 9, p. 335341, 2015.

PATRA, A. K.; SAXENA, J. Dietary phytochemicals as rumen modifiers: a review of the effects on microbial populations. Antonie van Leeuwenhoek, Oxford, v. 96, n. 4, p. 363-375, 2009.

RIBEIRO, C. G. S.; LOPES, F. C. F.; GAMA, M. A. S.; MORENZ, M. J. F.; RODRIGUEZ, N. M. Productive performance and fatty acid composition of milk from dairy cows fed increasing levels of sunflower oil in elephant-grass based diets. Arquivo Brasileiro de Medicina Veterinária e Zootecnia, Belo Horizonte, v. 66, n. 5, p. 1513-1521, 2014.

ROY, N. C.; KNIGHT, T. W.; REYNOLDS, G. W.; DEIGHTON, M. H.; DEATH, A. F.; SINCLAIR, B. R.; PETERS, J. S.; McNABB, W. C. The effect of condensedtannins in fresh Sulla (Hedysarum coronarium) on the net flux of fatty acids across the mammary gland and their secretion in the milk of lactating ewes. Proceedings of the New Zealand Society of Animal Production, Palmerston North, v. 62, p. 231-235, 2002.

SHINGFIELD, K. J.; BERNARD, L.; LEROUX, C.; CHILLIARD, Y. Role of trans fatty acids in the nutritional regulation of mammary lipogenesis in ruminants. Animal, Cambridge, v. 4, n. 7, p. 1140-1166, 2010.
SHINGFIELD, K. J.; ROUEL, J.; CHILLIARD, Y. Effect of calcium salts of a mixture of conjugated linoleic acids containing trans-10, cis-12 in the diet on milk fat synthesis in goats. British of Journal Nutrition, Cambridge, v. 101, n. 7, p. 1006-1019, 2009.

SILVA, B. C. M.; RODRIGUEZ, N. M.; MORENZ, M. J. F.; GAMA, M. A. S.; MARTINS, C. E.; PACIULLO, D. S. C.; GOMIDE, C. A. M.; ANJOS, A. J.; MADEIRO, A. S.; LOPES, F. C. F. Milk fatty acid profile of Holstein $x$ Gyr cows on 'Marandu' grass pasture under different grazing strategies. Pesquisa Agropecuária Brasileira, Brasília, v. 52, n. 8, p. 652-662, 2017.

SKLAN, D.; ASHKENAZI, R.; BRAUN, A.; DEVORIN, A.; TABOR, K. Fatty acids, calcium soaps of fatty acids, and cottonseeds fed to high yielding cows. Journal of Dairy Science, Champaign, v. 75, n. 9, p. 2463-2472, 1992.

TIEMANN, T. T.; LASCANO, C. E.; WETTSTEIN, H.R.; MAYER, A. C.; KREUZER, M.; HESS, H. D. Effect of the tropical tannin-rich shrub legumes Calliandra calothyrsus and Flemingia macrophylla on methane emission and nitrogen and energy balance in growing lambs. Animal, Cambridge, v. 2, n. 5, p. 790-799, 2008.

TORAL, P. G.; CHILLIARD, Y.; ROUEL, J.; LESKINEN, H.; SHINGFIELD, K. J.; BERNARD, L. Comparison of the nutritional regulation of milk fat secretion and composition in cows and goats. Journal of Dairy Science, Champaign, v. 98, n. 10, p. 7277-7297, 2015.

TURPEINEN, A. M.; MUTANEN, M.; ARO, A.; SALMINEN, I.; BASU, S.; PALMQUIST, D. L.; GRIINARI, J. M. Bioconversion of vaccenic acid to conjugated linoleic acid in humans. The American Journal of Clinical Nutrition, Rockville, v. 76, n. 3, p. 504-510, 2002.

VASTA, V.; MAKKAR, H. P. S.; MELE, M.; PRIOLO, A. Ruminal biohydrogenation as affected by tannins in vitro. British of Journal Nutrition, Cambridge, v. 102, n. 1, p. 82-92, 2009a.

VASTA, V.; MELE, M.; SERRA, A.; SCERRA, M.; LUCIANO, G.; LANZA, M.; PRIOLO, A. Metabolic fate of fatty acids involved in ruminal biohydrogenation in sheep fed concentrate or herbage with or without tannins. Journal of Animal Science, Champaign, v. 87, n. 8, p. 2674-2684, 2009 b.

VASTA, V.; YANEZ-RUIZ, D. R.; MELE, M.; SERRA, A.; LUCIANO, G.; LANZA, M.; BIONDI, L.; PRIOLO, A. Bacterial and protozoal communities and fatty acid profile in the rumen of sheep fed a diet containing added tannins. Applied and Environmental Microbiology, Washington, v. 76, n. 8, p. 2549-2555, 2010. 
VLAEMINCK, B.; FIEVEZ, V.; DEMEYER, D.; DEWHURST, R. J. Effect of forage:concentrate ratio on fatty acid composition of rumen bacteria isolated from ruminal and duodenal digesta. Journal of Dairy Science, Champaign, v. 89, n. 7, p. 2668-2678, 2006.
YANG, B.; CHEN, H.; STANTON, C.; ROSS, R. P.; ZHANG, H.; CHEN, Y. Q.; CHEN, W. Review of the roles of conjugated linoleic acid in health and disease. Journal of Functional Foods, Amsterdan, v. 15, p. 314325 , may 2015. 